\title{
Article \\ Educational Innovation in the Evaluation Processes within the Flipped and Blended Learning Models
}

\author{
Monserrath Yangari ${ }^{1, *, t, \pm(1)}$ and Esteban Inga $2, \neq(\mathbb{D}$ \\ 1 Master's Program in Educational Innovation, Universidad Politécnica Salesiana, Quito 170525, Ecuador \\ 2 Master's Program in ICT for Education, Smart Grid Research Group, Universidad Politécnica Salesiana, \\ Quito 170525, Ecuador; einga@ups.edu.ec \\ * Correspondence: eyangaris@est.ups.edu.ec; Tel.: +593-992-808-415 \\ + Current address: Postgraduate Department, Girón Campus, Av. 12 de Octubre N 23-52, \\ Quito 170525, Ecuador. \\ $\ddagger$ These authors contributed equally to this work.
}

Citation: Yangari, M.; Inga, E. Educational Innovation in the Evaluation Processes within the Flipped and Blended Learning Models. Educ. Sci. 2021, 11, 487. https://doi.org/10.3390/ educsci11090487

Academic Editors: Francisco D. Guillen-Gamez, Sandra Vázquez Toledo, Cecilia Latorre Cosculluela

Received: 7 July 2021

Accepted: 17 August 2021

Published: 31 August 2021

Publisher's Note: MDPI stays neutral with regard to jurisdictional claims in published maps and institutional affiliations.

Copyright: (c) 2021 by the authors. Licensee MDPI, Basel, Switzerland. This article is an open access article distributed under the terms and conditions of the Creative Commons Attribution (CC BY) license (https:// creativecommons.org/licenses/by/ $4.0 /)$.
Abstract: Nowadays, several institutions and universities have employed Flipped and Blended Learning models in the educational context. Consequently, these models advance correctly in the classrooms; students become more able to build their knowledge and develop their skills with technological innovation that could be compared with studies based on technological achievements and accessible data Tics. Therefore, this article proposes educational innovation in the evaluation processes within the FL and BL learning models to ensure active and interactive education. In this work, a bibliometric analysis of 2000 scientific articles from the Web of Science and Scopus databases has been carried out, thus making it possible to identify countries and universities with constant and relevant use of these learning models, as well as a comparison with these databases of articles, citations and their global impact. On the other hand, a survey was conducted with 41 teachers of different subjects and 385 students from elementary school to high school using the Likert scale. The questions were represented in perception values with their respective analysis of results and evaluations about these learning models, technological resources, flexible curriculum, learning before class, autonomous learning, and future professional competencies, which will help us know the existing motivation between them.

Keywords: educational innovation; flipped learning; blended learning; information and communication technologies; educational evaluation

\section{Introduction}

Education today does not have time to know the individual learning differences and their problems, which have produced few opportunities to participate and cannot be exercised their initiative correctly. The traditional classroom has provided students with fewer opportunities to think and practice; therefore, it cannot effectively cultivate students abilities. The main objective is to make these new learning models known and implement them in education, the idea is to turn around the traditional learning process, and the classroom should be converted into a place of interaction between teachers and students, answering doubts, informing and discussing the subject, to achieve an improvement in the teaching-learning of the student.

The objective of this article is to propose educational innovation in the evaluation processes within the Flipped and Blended learning models, where the student must assume a much more active role of cooperative and autonomous work in their learning process, than the one they have been assuming in the traditional way, implementing methodologies and active technological tools so that a deeper and more meaningful learning is promoted in the classroom, where the student is the protagonist of his own learning and the time to 
resolve doubts and consolidate knowledge in class is more extensive and concise, allowing to meet the diversity of the classroom.

Teachers must act as organizers within the classroom as they have a wealth of experience in the educational field and the ability to use information technologies to produce and manage learning resources in which the teacher is absent; therefore, blended learning is created, with online learning knowledge and offline knowledge to consolidate, find their problems and make feedback. Teachers have assigned previous tasks that are freely organized in their time and learning progress with the teacher's right technology tool until they achieve their goal.

The teacher has briefly reviewed the knowledge taught online, answers questions that students have in class, explain them, and guides the difficulties. These questions are based on videos of their self-learning and an evaluation questionnaire before class to know students' mistakes and guide them in a better way in a deep knowledge of learning the subject taught in class and thus be able to think and raise awareness problems the subject.

The interaction between students is a fundamental basis for implementing these models of education. To apply an evaluation in class, the teacher can group students according to their bases and interests and allow the development of a collaborative field in which ideas should have been exchanged. They propose their methods and steps to follow and thus allow us to learn and look at it from different perspectives and to inspire thinking, discussion, reflection and to analyze in-depth and find solutions to the problem; another innovative strategy is that the student can choose or design some topics close to life which can be used and applied with the knowledge taught in the classroom [1,2].

Implementing the FL and BL learning method has enhanced this process, increasing motivation and knowledge construction in the educational environment, where the student is responsible for his or her learning, which facilitates connectivity between students and teachers [3].

The hybrid model has represented the underlying system of interest, which broadens the discipline by combining theories and tools from across disciplines and applying multidisciplinary, interdisciplinary, and trans-disciplinary solutions to practice [4].

These teams are composed of researchers from these disciplines who have tried to solve a problem that requires the support, in this case of teachers and authorities involved in carrying out an educational innovation recognizing common problem areas and research objectives that require more permanent cooperation, which has provided a vision of methodological aspects and the support of technological tools.

There is a remarkable improvement in learning effectiveness using blended and inverted model tools compared to traditional tools. For educators who have sought the transition from passive learning to interactive learning to create new experimental classrooms, it is imperative to note that the current generation is highly technology-driven. Therefore, digital pedagogues must be used, which acquire great importance in this field of study. It must take into account that our students are accustomed to indigenous learning. An abrupt change could negatively disrupt it, so teachers must seek the proper pedagogy of traditional and digitally advanced participation to engage in meaningful inquiry-based learning.

Developed countries have experienced major curricular and pedagogical reforms and implemented various learning models driven by traditional tools in conjunction with technology. This situation creates in students the use of digital platforms for multiple purposes. Many academic institutions use BL tools such as MOOCs, simulation games, webinars, and blogs; however, it must be emphasized that teachers and students need to be prepared for this significant change in current and future generations.

However, the challenges that each of these countries are proposing to improve their education day by day are to get the best benefits of quality instruction delivered to students. The inclusion of technology in flipped and blended learning models is considered the most effective and most popular mode adopted by education, which will always benefit from perceiving effective and continuous learning $[5,6]$. 
The teacher should not be replaced by digital platforms, since learning and knowledge creation is a co-creative process which encompasses emotional quotient, social learning, self-learning and is effectively generated through the teacher, for which one must be trained to be able to design a strategy that most efficiently contemplates the development of knowledge.This strategy should use this learning in class, which makes it genuinely experiential, and these approaches help to play the most crucial role, which has been to guide students to the highest levels of application and become a cost-effective tool that can help the flexibility of education to adapt to these new changing environments [7].

The teacher must be trained and prepared with the use of Information and Communication Technologies (ICT), which in turn has required the teacher to acquire digital skills to respond to the needs of the student, trying to replace homework with interactive resources where students combine their classroom learning with digital technologies, the use of the Learning Management System (LMS), are tools that allow easy and organized access to digital resources that teachers must prepare for their students, for which requires ongoing assistance from the authorities in updating methodologies and tools essential to implement these learning models in the classroom, student engagement is critical as it provides benefits such as flexibility and mobility of learning and the ability to manage cognitive load [8]. It leads to improved critical thinking skills and an engagement with both materials and peers, and personal satisfaction, which has positive effects on psychological well-being and positively impacts students in their learning environment.

Digital technologies will be used by the student in the process of FL and BL to offer and receive experiences in their time outside the classroom, where the student is responsible for their self-directed learning and, in doing so, will develop activities of permanent knowledge [9]. It will proceed to socialization with the teacher and contribute to what they are learning using collaborative, cooperative, and problem-based learning strategies. The teacher continuously evaluates the evaluation to the student to know their skills and abilities in this new field of learning study.

However, these models should be raised again and continue to be put into practice to help in their maximum capacity in student performance. The role of the teacher should be emphasized in its importance for this approach to be successful; there should be open communication between colleagues to give their opinions about the implementation of these learning models in the classroom and to clarify that there can be failure and perfectionism, what matters is to be able to experience failures and risks from time to time. Teaching methods should be adjusted so that the teacher can self-criticize if it is noticed that something is not working and start implementing exercises and new feed backs that favor the best learning [10], a role of facilitator and evaluator of students' learning performance should be taken.

Therefore, through an online environment, instructions will be provided and carefully selected and designed to support face-to-face and online learning. Students should always be analyzed to identify their preferences, characteristics, learning environment and learning styles to plan and design strategies that help build and develop thinking in class. There are many reasons why these models should be implemented within the classroom, in which there are two essential points to be able to apply these concepts. The learning experience should be increased and adopted in new support for learning through technology and its easier access, and thus the educational processes of both the student and the teacher should be improved [2,11].

This article is organized as follows. Related works with the research are described in Section 2. The problem formulation is presented in Section 3. Analysis of Results is presented in Section 4. Finally, some conclusions are giving in Section 5.

\section{Related Works}

The teacher imparts knowledge to many students, who will have been transformed into passive receivers as they only watch and listen. This approach can be practical for the 
content presented in a fast-paced manner; however, it has many limitations, treating all students equally with limited preparation, and their feedback is often [12].

Active learning pedagogies are incorporated with these models; therefore, active participation in classrooms and a contribution by the student to assess their prior knowledge and then various learning strategies are used by the teacher as well as collaborative, cooperative and problem-based [9]. In an inverted format, structures already exist, such as low-stakes daily quizzes, so students will be held accountable for work done outside of class [13].

Technological advances in synchronous environments have offered benefits to learners in terms of flexibility, the interaction between participants, the exchange of knowledge, experiences and real-time feedback between teacher and student [14]. Different types of classrooms can be created, and the combination of synchronous cyber classrooms, electronic whiteboards, interactive response systems, and the existing relationship with FL and BL learning models $[15,16]$.

In the framework of education, autonomous learning, based on the individual student's needs and their self-construction of knowledge through online resources and likewise, in the classroom, face-to-face students discuss, communicate and share ideas, and a blended learning MOOC. Pays much more attention to the students' experience throughout their process, which meets the student's needs of different levels of learning and likewise a real help to the teacher [17].

Information and Communication Technologies (ICT) or open online courses have penetrated the educational ecosystem making known the future of a globalized education using these study models [18].

However, this transformation requires the teacher to be a leader in the classroom who must have an area of competence of professional knowledge and assessment that has a crucial role in education to know the development and skills acquired by the student [19].

The recent achievements offered by these models in education have been several since they constitute a significant added value in students using various technological tools which are an essential aid in the acquisition of new knowledge, all the changes and challenges proposed by these authors have been reflected in the requirements and demands of universities that have adopted these models [20].

There are several countries in which modern learning models have been used that have been effective teaching-learning processes. On the other hand, the technological resources used in class do not always become the best for students. Since some of them, present problems of connectivity, video quality, handling of students who come to class without reviewing such resources and also the possibility that students ask questions while watching the video and do not get direct answers are several of the weaknesses that adopt these learning models in several countries [21].

There are two types of flipped classrooms. The flipped mastery model is used in classrooms as it aims for a standard reach above a certain level, this type of inverted classroom is taught in classes to instruct individual students who do not learn enough in a face-to-face classroom. The flipped classroom and blended learning have increased student attendance and decreased their failure rate.

On the other hand, the other type of inverted classroom has been used as an advanced and high capacity learning model in which will have been taught more complex contents, and its purpose is to increase student's knowledge. This method of the flipped classroom has been used in several establishments with excellent results. Consequently, it has been proposed that students are divided into three groups with a record of self-study time and degree of understanding and then will have a face-to-face class and should be verified the status of students in their learning; the groups have been comprised between students who can understand the contents.

Consequently, students who cannot understand because they have not studied the resources sent by the teacher and students who cannot understand even though they study on their own for a long time. So, this learning model has been more effective in 
the grouped inverted classroom than the conventional inverted classroom, in which the teacher sends material and self-learning performance tests at home and at school in the same way performance tests and technological resources and finally, a final evaluation. The teacher who guides with these results should be made support material for each group and start safe feedback [22].

The FL model has been identified several ways to implement this approach in classes, in which some links should be used as tests, frequently asked questions, cooperative exploration, individualized guidance, exercises and summative evaluation. In which technological resources have been made by the teacher for the development of the student before the class so that it is of great interest, a reasonable level, challenging, rewarding and the teacher is not entirely excluded and has constant interaction with the student virtually, either by mail, messages, chat blogs.

These learning models have always been written with a didactic objective: memorising, understanding, application, analysis, evaluation and creation. For an evaluation of performance in ordinary time, it should be evaluated through class participation, which includes a previous task plus the scoring of the activity and an evaluation within the group among themselves, to know the correct performance of each student and their skills acquired within the classroom and the proposed topic. In this way, both the student and the teacher will have clear objectives before the class, and it will be beneficial for a deep understanding of knowledge and the teacher [23].

Teachers have been able to evidence this acquired knowledge through various forms of assessment: experiments, games, online learning, readings, study groups, and feedback will be successfully conducted in the group, among the students should be immediately appreciated if these models are effective as they present enthusiasm, learning attitudes and participation for which the class interaction will be carried more efficiently, and the students themselves will be more independent in their activities, in conclusion, the students will have an increase in quality in their daily learning, which has a significant difference with the problems that were initiated in the educational environment [24].

Within the analysis, it has been evidenced that these learning models are more used in private institutions with few students because they have innovative digital tools and teacher and student training. As well as universities, since the student is responsible for their self-directed learning and in doing so develops the skills of lifelong learning, which has been shown that learning with digital technology has provided benefits to students both as flexibility and mobility, with these models it is desired that the student comes to have a so-called "new normal" in education [25].

The passive methodology has been based on organization, sequencing and the use of active periods; typically, activities are worked on the contents, and in this case, the problems and doubts can be left to be solved at home. On the other hand, the use of FL, a methodology centered on constructive and social learning theory, has been proposed. It has been oriented to make the student the protagonist of his or her learning [26].

Figure 1 shows the methodological process required to perform a bibliometric analysis that will reduce the risk in empirical research processes in the field of education and particularly in evaluation by applying the FL and BL model.

On the other hand, there has been increasing pressure for the educational community to undergo a transformation that allows for flexible solutions that support teaching objectives, provide students with new activities, increase opportunities for active learning in the classroom, and improve students' digital literacy and lifelong skills [27].

The educational process is contextualized, which are the object of review due to the importance of a teacher having the necessary competencies to face a technological change. It should be trained for its use, management and subsequent didactic implementation in the classroom; this means being competent, being a teacher of the XXI century, in which he/she can develop skills, aptitudes and knowledge necessary to perform specific tasks. 


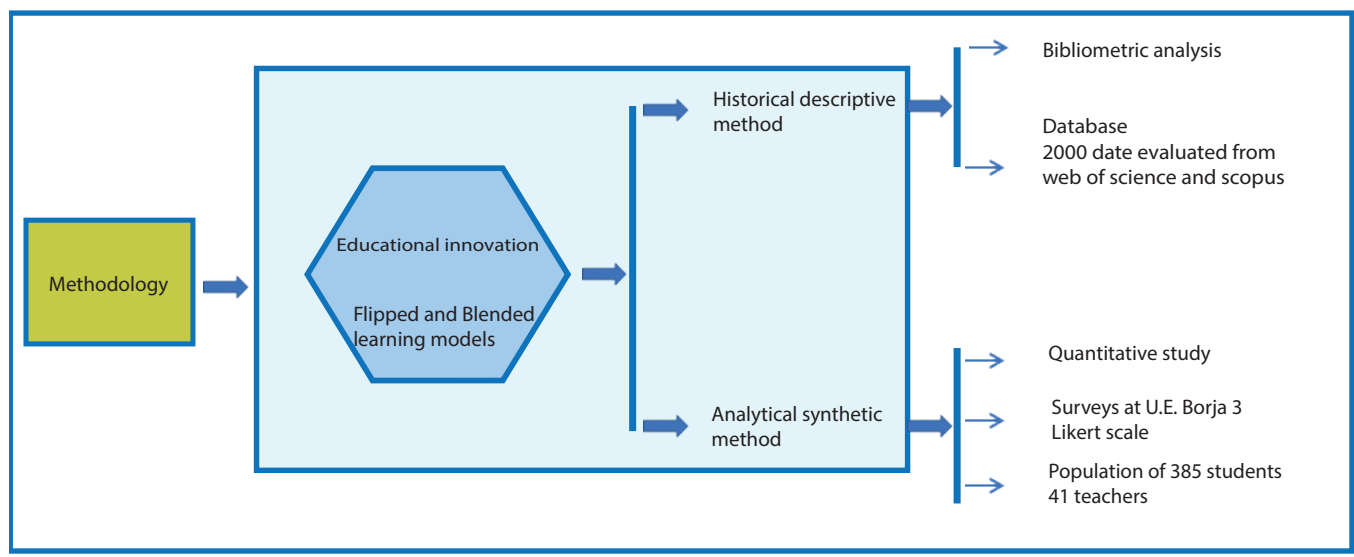

Figure 1. Methodological process. Source: Authors.

Table 1 shows the innovative technological achievements based on ICT (Information and Communication Technologies). Skills and technological innovation, didactic and the teaching-learning process taught in the classroom has allowed identifying evolutionary trends in each of the countries where the innovative process has been interpreted in technological skills, as shown in countries such as Colombia, Chile, Argentina, Brazil and Mexico that are in constant evolution.

Table 1. Technology achievement according to data set from Zenodo 2018.

\begin{tabular}{lll}
\hline Technological Skills & Technological Innovation & Countries \\
\hline Information and communication & Teaching-learning processes & Colombia \\
technologies & Innovative process & Chile \\
Skills development & Educational innovation generators & Argentina \\
Skills & Didactic materials & Brazil \\
Classroom didactic & Teacher professionalization & Mexico \\
Teaching strategies &
\end{tabular}

Figure 2 shows that the United States has been one of the countries with the most research on inverted and blended learning models in both Web of Science and Scopus databases. When comparing these graphs, it can be seen that in the first database, there are more countries with research in this area and countries such as China, Spain, Australia.

These countries have innovative thinking in education and an approach that has facilitated the experience of better learning and lead to active knowledge building. These universities have tried to create a role of growth and evolution in the fields of education.

These learning models in high-level countries have been the first to acquire new activities which will be flexible and with a degree of freedom so that students can choose their projects and have the facility to acquire and improve their knowledge [28], it can be stated that teachers are not only the providers of knowledge but also facilitators of learning [29].

The educational process is contextualized, which are the object of review due to the importance of a teacher having the necessary competencies to face a technological change. It should be trained for its use, management and subsequent didactic implementation in the classroom; this means being competent, being a teacher of the XXI century, in which he/she can develop skills, aptitudes and knowledge necessary to perform specific tasks. 


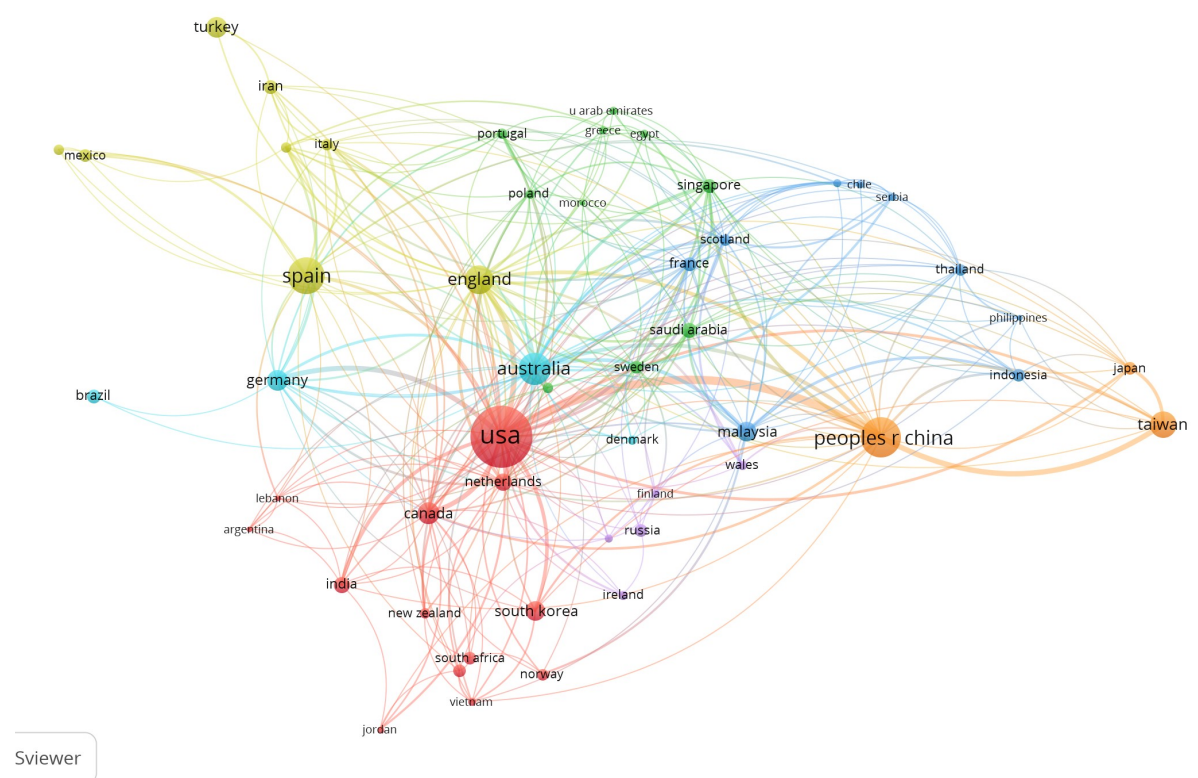

(a) Web of Science Data - Countries-FL

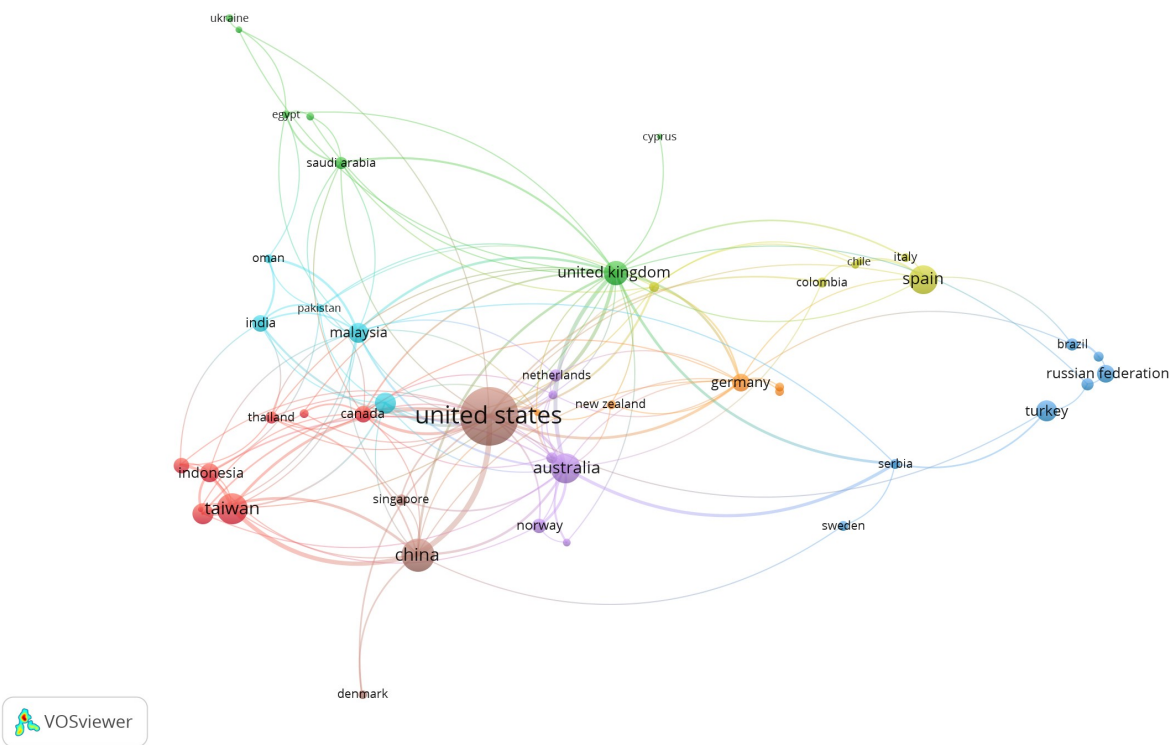

(b) Scopus Data —Countries-FL

Figure 2. Bibliometric Analysis: Network map showing the relations between various Countries in the Flipped and Blended Learning \& Education. (a) Web of Science (WoS). (b) Scopus. Source: Authors.

\section{Problem Formulation and Methodology}

Education today has been based on the traditional school using passive and obsolete methods, in which the teacher is the guide. Still, the student will not have to interact correctly in the classroom, for this reason, the teaching-learning process becomes more extended, and even their feedback will take longer than proposed.

In Figure 3 by executing an educational innovation in the classroom using as a primary point the motivation of both the student and the teacher in the new models of FL and BL learning, interactive learning takes place and the construction of knowledge is developed, using the historical descriptive and synthetic analytical method, the learning process can be optimized and with the surveys carried out with the Likert scale, a new ideology of the role of the teacher and the student will be obtained to obtain an evaluation process that conceives a positive cause and effect in the classroom, through constant evaluation processes such as questionnaires, oral lessons, projects, games, it will be verified that 
the student has deepened in class and must participate with innovative thinking and an integral learning result.

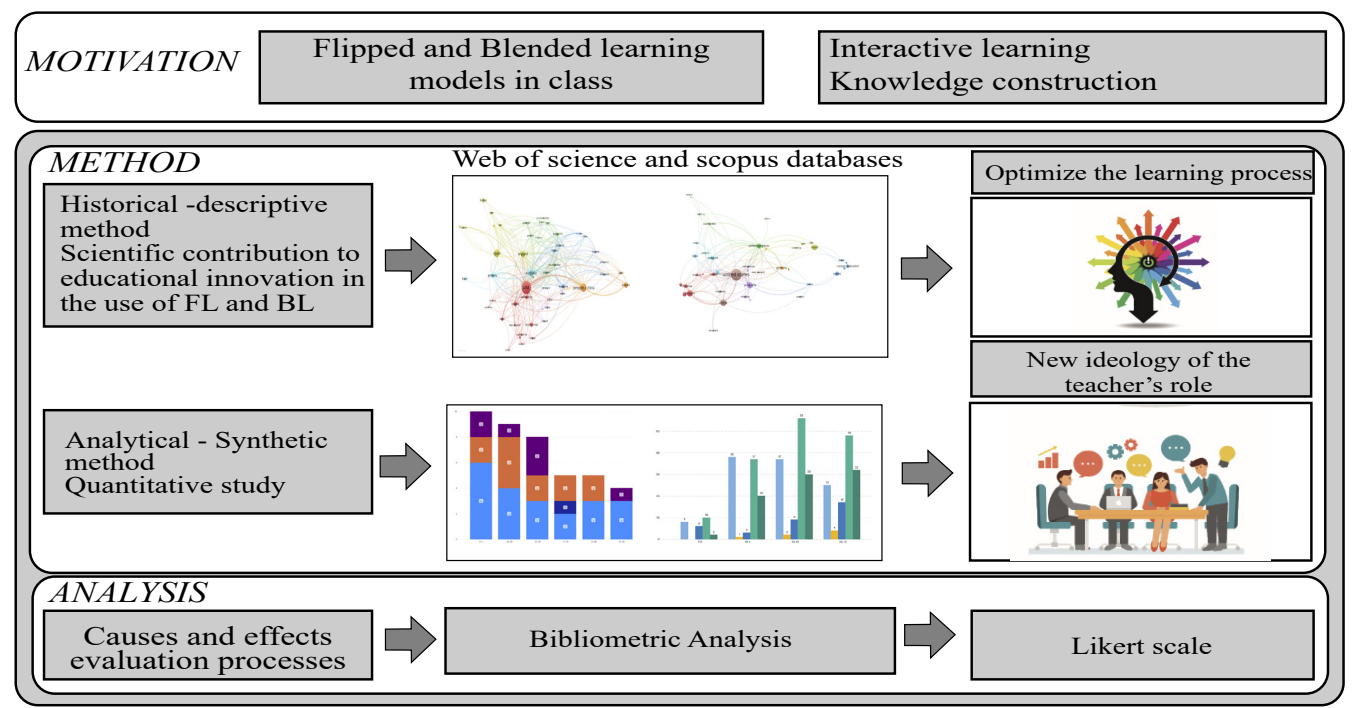

Figure 3. Educational Innovation in the Evaluation Process within the Flipped and Blended Learning Model. Source: Authors.

Flipped learning as a pedagogical model has gained originality and importance in recent years and with it one learns by doing and not by memorizing, precisely in the survey of students and teachers highlights the motivation and interest to participate and learn more about these learning models in the classroom and that students better develop their knowledge independently.

This methodology is revolutionary in nature as it proposes a radical change to the educational system, students and teachers admit that a change would be paramount in the use of technological tools, virtual platforms, videos and interactive work with more participatory activities (debates, group work, ideas, reflections, etc.), all supported by new technologies and with the teacher as their guide.

Implementing the Flipped Learning and Blended Learning models should note that the teacher continues to be a leader. Still, the student becomes an active character in the educational process. The evaluation, which should be continuous in the classroom, is carried out efficiently by study groups, which can be separated according to the student's knowledge and evaluated in this way to be able to give correct feedback according to the student's needs.

The evaluation must be continuous in the classroom; it is carried out efficiently by study groups, in which it can be separated according to the student's knowledge and evaluated in this way in order to be able to give correct feedback according to the student's needs.

Based on the historical and descriptive method, scientific articles will be evaluated with a global and regional focus. In addition, a bibliometric analysis will be carried out through Vos Viewer to identify the countries with the most significant scientific contribution in Educational Innovation applying inverted learning (FL) and blended learning (BL) models, the most relevant researchers about the number of citations, the universities that present research in this field of study and the countries with the most significant scientific contribution in the use of these learning models $[6,16]$.

The database evaluated from Web of Science and Scopus as the largest and most important sources. The 2000 data were evaluated with specific keywords such as Innovation Education and Flipped Learning or Blended Learning. Consequently, the Evaluation process allowed us to know the incidence of using these learning models in an educational environment. 
Analysis bibliometrics is used to investigate the interpretations of the professionals who have used these learning approaches; interviews could be conducted, which can serve as a valuable and legitimate empirical research method to obtain internal knowledge of the process on these new learning models. These professionals who have obtained results with implementing these new strategies in the classroom are responsible for this development, who understand the abstract ideas since they have analyzed the structure of these problems, analyzed them, organized them, and produced logical and appropriate solutions with more accessible knowledge and strategies.

The bibliometric analysis as a study and based on important databases in countries, universities and authors have acquired a remarkable development, as they provide us with relevant information on the current state of these areas of knowledge giving us to know standards of references in this research and pointing out that the Flipped and Blended Learning models have taken great opening in the development of skills, abilities and competencies in their different fields of study, thus obtaining results that have influenced the methods applied in this study that aims to go to the discovery and review the effects by students and teachers to improve and innovate education.

The Table 2 is presented with the countries with more documents and citations about the use of the inverted and blended learning model. In this table, we can compare the countries that have more research according to databases, in which it can be observed that Web of Science according to countries has more documents and information than Scopus, which concludes that in this database there is more incidence of research on FL and BL learning models.

The modern world has become a great place where great varieties of technology emerge, which come become a fundamental part of education in all its fields; the uses of technological tools have innovated teaching-learning in the most powerful countries, which express their knowledge every day with more resources and innovative methodologies [30].

Table 2. Most influential Countries of Flipped \& Blended Learning strategies.

\begin{tabular}{llllll}
\hline \multicolumn{5}{c}{ Bibliometric Analysis } \\
\hline Web of Science & & Scopus & \\
\hline Country & Documents & Citations & Country & Documents & Citations \\
\hline USA & 569 & 2505 & USA & 413 & 3085 \\
Australia & 148 & 1360 & Taiwan & 115 & 1230 \\
China & 238 & 1042 & Australia & 106 & 816 \\
England & 118 & 747 & Hong Kong & 56 & 801 \\
Spain & 200 & 676 & Spain & 102 & 670 \\
Malaysia & 55 & 508 & China & 113 & 624 \\
Taiwan & 104 & 478 & Turkey & 55 & 514 \\
Belgium & 23 & 451 & UK & 70 & 445 \\
Canada & 66 & 406 & South Korea & 52 & 333 \\
Germany & 64 & 352 & Belgium & 10 & 225 \\
\hline
\end{tabular}

Critical thinking skills in students have been considered a fundamental educational objective in which inquiry learning is used to become an independent problem solver and uses the FL model in the classroom without any inconvenience [31].

Active learning in students drives to achieve a high educational level with problemsolving, students' responsibility and effort, and demanding teacher training. The education systems of several countries have worked with innovative technology, ICTs, teaching materials, virtual platforms, gamification, and several tools according to students and teachers' needs to achieve significant progress.

Technological innovation plays a fundamental role, not only with the incorporation of new technologies into teaching processes; moreover, with the work on mass media, the expansion of training areas, the development of new teaching materials, the profes- 
sionalization of teachers, the rethinking of objectives and teaching strategies that lead to show evolutionary indicators in development. In countries with the more negligible effect, it has been necessary to implement better strategies that allow them to stand out in technology and innovation, applying criteria of good practices of investments in science and technology to stand out and be generators of educational innovations.

On the part of universities, their articles are scarce, but their citations represent the use of these learning models with a global and representative approach, which generates a new learning environment that has led to a change in the roles and habits of students and teachers.

Table 3 presents the universities with more citations in the field of education concerning the use of inverted and combined learning models. Organizations have been the main ones in acquiring these new concepts of change in teaching-learning, databases have been used to compare the research conducted in these universities in which we can see that Web of Science has a greater relevance of universities which apply in their educational environment these models of inverted and combined learning compared to the Scopus database table.

Although several education models undergo quality changes in an educational system that follow an experimental pattern designed to achieve practical knowledge development following an evaluation process, we will know the best results of the behavior, creativity, and flexibility of these models in students. (W. T. Chen et al., 2018).

Table 3. Most influential Universities of Flipped \& Blended Learning strategies.

\begin{tabular}{|c|c|c|c|c|c|}
\hline \multicolumn{6}{|c|}{ Bibliometric Analysis } \\
\hline \multicolumn{3}{|c|}{ Web of Science } & \multicolumn{3}{|c|}{ Scopus } \\
\hline University & Documents & Citations & University & Documents & Citations \\
\hline Malaya Univ & 15 & 259 & Univ of Hong Kong & 6 & 174 \\
\hline Ghent Univ & 9 & 254 & $\begin{array}{l}\text { National Taiwan } \\
\text { Univ }\end{array}$ & 11 & 155 \\
\hline Politekn negeri medan & 5 & 199 & Taiwan Univ & 2 & 122 \\
\hline Vrije Univ brussel & 7 & 177 & $\begin{array}{l}\text { Univ of belgrade, } \\
\text { serbia }\end{array}$ & 2 & 113 \\
\hline Univ Sydney & 13 & 171 & UK Univ & 1 & 96 \\
\hline Univ Technol Sydney & 7 & 168 & $\begin{array}{l}\text { Univ Sydney Aus- } \\
\text { tralia }\end{array}$ & 1 & 96 \\
\hline Univ Texas Austin & 9 & 158 & $\begin{array}{l}\text { Univ of South Aus- } \\
\text { tralia }\end{array}$ & 1 & 96 \\
\hline Univ Stockholm & 6 & 153 & Asia Univ Taiwan & 2 & 76 \\
\hline Karolynska inst & 6 & 395 & $\begin{array}{l}\text { Nat Central Univ, } \\
\text { Taiwan }\end{array}$ & 3 & 76 \\
\hline Univ Melbourne & 8 & 138 & $\begin{array}{l}\text { Univ of science and } \\
\text { tech, Taiwan }\end{array}$ & 9 & 73 \\
\hline
\end{tabular}

Table 4 presents the authors with more documents and citations about the practice of the inverted and blended learning models, according to this table we can distinguish the authors who have more studies according to databases, where it can be observed that Scopus has a large number of documents and citations than Web of Science and to note that in this database there is more impact of research on FL and BL learning models.

An Analytical-Synthetic method will be applied to observe the causes and effects that these learning models will have in the educational environment, should be analyzed surveys if the students have a motivating initiative concerning these new models. With evaluation processes, it will be known if these students have obtained a better construction of knowledge or a teacher and student training must introduce new technological tools that should be implemented using the FL and BL in the classrooms.

This research has been based on a quantitative study to collect perceptions on the usefulness of the methodology. In its construction, will be evaluated the didactic resources, strategies and methodologies. Therefore, the Likert Scale has been used, which is a type 
of ordinal scale to obtain more clearly the opinion and valuation of the respondents, with which it will intend to measure the attitude towards a predetermined topic.

Table 4. Most influential Authors of Flipped \& Blended Learning strategies.

\begin{tabular}{|c|c|c|c|c|c|}
\hline \multicolumn{6}{|c|}{ Bibliometric Analysis } \\
\hline \multicolumn{3}{|c|}{ Web of Science } & \multicolumn{3}{|c|}{ Scopus } \\
\hline Author & Documents & Citations & Author & Documents & Citations \\
\hline De wever, bram & 5 & 215 & Hew k.f. & 13 & 391 \\
\hline Ong, hwai chyuan & 6 & 205 & Lo c.k. & 12 & 381 \\
\hline Masjuki, h. h. & 5 & 192 & Hwang g.-j. & 21 & 257 \\
\hline Kusumo, f. & 4 & 186 & Pardo a. & 8 & 177 \\
\hline Silitonga, a. s. & 4 & 186 & Gašević d. & 7 & 173 \\
\hline Zhu, chang & 6 & 166 & Chen $\mathrm{f}$. & 2 & 170 \\
\hline Dharma, s. & 3 & 137 & Martinelli s.m. & 2 & 170 \\
\hline Sebayang, a. h. & 3 & 137 & Wu w.-c.v. & 3 & 158 \\
\hline Valcke, martin & 3 & 111 & Jovanović j. & 5 & 143 \\
\hline Car, lorainne tudor & 7 & 91 & De wever b. & 3 & 123 \\
\hline
\end{tabular}

For this purpose, was prepared a survey with 26 questions, including informative data on the use of technological tools, information and communication technologies (ICTs), the use of Flipped Learning and Blended Learning models in the classroom, acquisition of new knowledge, virtual environments, formative evaluation, feedback, autonomous learning, active participation, to which the respondents had to express their degree of agreement or disagreement.

The survey was conducted at "Unidad Educativa Borja 3 Cavanis" in Quito among students from fifth grade to the third grade of high school. Three parallel surveys were conducted for each grade, with a population of 385 students and 41 teachers of different subjects of the institution.

The characteristics of the students used would be: the total time dedicated to reviewing the technological resources, time dedicated to the class, homework and evaluations to know the skills acquired by the student, which will give us to know the effort of each one of them, it is equally important to control in the classroom the working conditions and classmates for the coefficient of interest.

An update of the concept of teacher evaluation has become indispensable from its attitude, preparation, contents, methods and means of teaching effectiveness, which would be the indispensable basis for implementing these models in the classroom and an initial acquisition and construction of this knowledge [32].

Several dimensions have characterized the Common Framework for Digital Teaching Competence: Communicative, which focuses on the construction, reconstruction and presentation of information and will assess the possibilities that exist to be able to transfer the content, in such a way should allow the constructive use of language and understanding of these same, several skills have been included in this dimension and actions linked to the development [33].

On the other hand, must be analyzed the characteristics and functions of its elements with the instrumental dimension to enhance the inverted classroom that allows facing problems or situations of technological resources; this means developing cognitive skills as a result of its implementation in the training processes. Finally, the pedagogical dimension, which examines the teaching and learning processes, analyses the didactic possibilities of the methodology and has focused on aspects such as the evaluation and regulation of learning, which will allow the use of this methodology in the acquisition of educational skills and the development of students to be evaluated [26].

Several methods could be included as technological tools based on a learning management system, such as Moodle, in the teaching process. This platform is designed teaching system that has been created to manage online learning spaces adapted to the needs of 
teachers and students in other terms, a dynamic web system created to manage virtual teaching environments, which can be used to assess students and know their knowledge having applied new learning models such as BL.

Evaluation has always been considered a key element in all collaborative dynamics. The feedback is an essential strategy for reasonable construction of thinking in acquiring new skills in virtual environments, which must consider in learning contexts, circumstances and deadlines [34].

Research should always be designed and involve students with physical and cognitive disabilities since good learning is needed [35]. It will need new technological tools before the class and then specific resources for this group and a personalized evaluation to know the progress and what kind of feedback can be done to obtain better results in these students.

According to the Likert scale based on 5 points mainly used in this research for students' understanding of opinions and attitudes, it has been used as P1 agree, P2 agree, P3 undecided, P4 in disagreement, and P5 strongly disagree to obtain the required information by students and teachers responses through the applied survey.

It can be observed according to Table 5 that students present a greater breadth of criteria in items 1 and 2 due to the use of new technological tools in the classroom such as virtual platforms, games, videos, the acquisition of new knowledge, interactive evaluations, collaborative work, and the use of the three moments offered by Flipped Learning in the classroom with students.

On the other hand, many students find satisfaction in receiving classes online rather than face-to-face using virtual platforms, and a similar percentage of students have problems assimilating new knowledge virtually.

On the contrary, in the Likert scale, it has been observed in the Table 6 that most teachers agree with the use of technological resources in the classroom since they favor the acquisition of learning. Therefore special courses are required for the management of ICT. Likewise, a new learning model is considered necessary in the classroom that develops innovative and collaborative knowledge in the student, such as the Flipped and Blended learning models in class, which aim to move from a passive student to an active and autonomous one.

According to the survey applied, a majority of teachers have felt able to learn autonomously new technological resources through the use of the Internet on YouTube. It has become a fundamental tool when reinforcing content that has not been understood in class or learning new things that complement a new knowledge because the tutorials are explained step by step for proper understanding. Thus teachers have the opportunity to learn new strategies to teach their class.

Likewise, a percentage of teachers have developed in class the three stages of the FL and BL model: a review of video classes at home, meeting with the teacher - reinforcement and homework to assimilate knowledge and evaluate the process. 
Table 5. Survey based on 5-point Likert scale by Students.

\begin{tabular}{|c|c|c|c|c|c|}
\hline Survey & P1 & P2 & P3 & $\mathbf{P 4}$ & P5 \\
\hline $\begin{array}{l}\text { 1.Would you be interested in using more digital (technological) resources } \\
\text { in your class hours from home? }\end{array}$ & 151 & 108 & 84 & 7 & 35 \\
\hline $\begin{array}{l}\text { 2. Would you like your teachers to use interactive games more frequently } \\
\text { to liven up the teaching of subject matter in class? }\end{array}$ & 227 & 111 & 32 & 4 & 11 \\
\hline $\begin{array}{l}\text { Do you think that if your teacher uses new technological tools it will } \\
\text { hcrease your knowledge? }\end{array}$ & 137 & 130 & 89 & 18 & 11 \\
\hline $\begin{array}{l}\text { 4. Do activities such as games or interactive videos help you better under- } \\
\text { stand a subject? }\end{array}$ & 177 & 134 & 49 & 13 & 12 \\
\hline $\begin{array}{l}\text { 5. Would you like to learn how to use new technological tools in the class- } \\
\text { room? }\end{array}$ & 188 & 147 & 34 & 6 & 10 \\
\hline lessons through interactive games? & 158 & 128 & 63 & 15 & 21 \\
\hline $\begin{array}{l}\text { 7. Do your teachers use digital tools in classes such as videos, games, vir- } \\
\text { tual environments, etc.? }\end{array}$ & 121 & 120 & 84 & 34 & 26 \\
\hline $\begin{array}{l}\text { 8. Do you think that doing group work among peers favors the under- } \\
\text { standing of a subject matter? }\end{array}$ & 146 & 92 & 79 & 27 & 41 \\
\hline $\begin{array}{l}\text { 9. Would you like to have more knowledge of the topic to be covered prior } \\
\text { to receiving the class with your teacher? }\end{array}$ & 113 & 122 & 94 & 18 & 38 \\
\hline $\begin{array}{l}\text { 10. Would you like your teachers to use a different way of teaching in } \\
\text { class? }\end{array}$ & 137 & 120 & 79 & 22 & 27 \\
\hline $\begin{array}{l}\text { 11. Do you find satisfaction in receiving virtual classes using virtual plat- } \\
\text { forms? }\end{array}$ & 94 & 82 & 118 & 50 & 41 \\
\hline 12. Are the tasks they send you clear enough for you? & 130 & 129 & 76 & 28 & 22 \\
\hline $\begin{array}{l}\text { 13. Is it difficult for you to perform tasks at home, are you easily dis- } \\
\text { tracted? }\end{array}$ & 60 & 78 & 98 & 63 & 86 \\
\hline $\begin{array}{l}\text { 14. Are the assignments and projects submitted by your teachers interest- } \\
\text { ing to you? }\end{array}$ & 96 & 94 & 112 & 37 & 46 \\
\hline 15. Do you have difficulty learning and acquiring new knowledge? & 36 & 56 & 81 & 95 & 117 \\
\hline $\begin{array}{l}\text { 16. Does your teacher motivate you in class when you go to learn new } \\
\text { topics? }\end{array}$ & 102 & 104 & 86 & 42 & 51 \\
\hline $\begin{array}{l}\text { 17. In class, when you have difficulty learning a subject, does your teacher } \\
\text { help you? }\end{array}$ & 152 & 152 & 50 & 16 & 15 \\
\hline $\begin{array}{l}\text { 18. Does your teacher use innovative technological tools to evaluate in } \\
\text { class? }\end{array}$ & 72 & 97 & 109 & 48 & 59 \\
\hline $\begin{array}{l}\text { 19. Have you used YouTube to acquire knowledge prior to the topics to be } \\
\text { covered in class? }\end{array}$ & 169 & 90 & 37 & 26 & 63 \\
\hline $\begin{array}{l}\text { 20. Do you think you could learn on your own (autonomously) using the } \\
\text { Internet and YouTube without the accompaniment of a teacher? }\end{array}$ & 74 & 68 & 83 & 52 & 108 \\
\hline $\begin{array}{l}\text { 21. Is the Internet access you have at home adequate for the number of } \\
\text { people living at home who are studying or teleworking? }\end{array}$ & 190 & 87 & 50 & 29 & 29 \\
\hline $\begin{array}{l}\text { 22. Do you work with your teacher on the } 3 \text { moments of the "flipped learn- } \\
\text { ing" model? } \\
\text { a. Review of video lessons at home. } \\
\text { b. Meeting with the teacher - Reinforcement. } \\
\text { c. Assignments to assimilate knowledge and evaluate the process. }\end{array}$ & 71 & 97 & 86 & 48 & 83 \\
\hline
\end{tabular}


Table 6. Survey based on 5-point Likert scale by Teachers.

\section{Survey}

P1 P2 P3 P4 P5

1. Do you believe that educational innovation is a fundamental element in the $\begin{array}{llllll}27 & 12 & 1 & 0 & 1\end{array}$ education of the present and future?

2. Do you believe that technological resources favor the acquisition of learn- $\quad \begin{array}{lllll}15 & 22 & 2 & 0 & 2\end{array}$ ing?

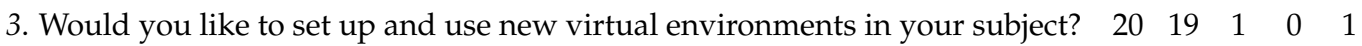

4. Do you consider that the use of information and communication technolo- $\begin{array}{rlllll}15 & 25 & 0 & 0 & 1\end{array}$ gies (ICT) in the classroom is indispensable?

5. Do you consider necessary special training courses in the use of ICT for $\quad \begin{array}{llllll}22 & 15 & 3 & 0 & 1\end{array}$ teachers?

6. As a teacher, do you think you need to use a new learning model for your $\begin{array}{lllllll}10 & 27 & 3 & 0 & 1\end{array}$ subjects?

7. Do you think you need training courses that include how to deliver new $\begin{array}{llllll}16 & 24 & 0 & 0 & 1\end{array}$ learning models in the classroom?

8. Do you think that a new learning model would motivate and achieve a new $16 \quad \begin{array}{lllll}18 & 4 & 1 & 1\end{array}$ attitude among students?

9. Would you like to implement in your subject a new learning model called $\quad \begin{array}{lllll}17 & 19 & 3 & 1 & 1\end{array}$ "flipped classroom", in which your students are active rather than passive entities?

10. Would you like to innovate the development of activities with a new learn- $\begin{array}{rrrrr}17 & 23 & 0 & 0 & 1\end{array}$ ing model using new and innovative digital tools?

11.Would you be interested in a new learning model where cooperative work $\begin{array}{lllllll}19 & 20 & 1 & 0 & 1\end{array}$ is generated?

12.As a teacher, do you believe that a new "blended" learning model that $\quad \begin{array}{llllll}14 & 23 & 2 & 1 & 1\end{array}$ mixes face-to-face encounters with technology-based learning could take advantage in knowledge development?

13.As a teacher, do you provide ongoing rubric-based assessment to your $\quad \begin{array}{llllll}17 & 19 & 3 & 0 & 2\end{array}$ students?

14.Does formative assessment using rubrics increase teacher workload? $\quad \begin{array}{lllllll}13 & 11 & 8 & 6 & 2\end{array}$ 15.Do you use several evaluation methods in your subjects? $\quad \begin{array}{llllll}20 & 0 & 0 & 19 & 1\end{array}$

16. Does the feedback provided to the student use various motivational re- $\quad \begin{array}{llllll}16 & 20 & 4 & 0 & 1\end{array}$ sources?

17. Is it important for the student to be autonomous in his or her learning and $\begin{array}{llllll}12 & 20 & 7 & 0 & 1\end{array}$ the teacher only his or her guide?

18. Do you believe that the student in the classroom needs active participation $\begin{array}{llllll}24 & 15 & 0 & 0 & 1\end{array}$ in his or her learning?

19. Do you think you need to update your skills and abilities to meet the de- $\quad \begin{array}{llllll}13 & 26 & 1 & 0 & 1\end{array}$ mands of current and future teaching practice?

20. As a teacher, do you believe that you can learn new ICT skills on YouTube $\quad \begin{array}{llllll}9 & 27 & 4 & 0 & 1\end{array}$ to improve the teaching process for your students?

21. As a teacher, do you believe that Vocational Guidance should be promoted $10 \begin{array}{lllll}10 & 28 & 2 & 0 & 1\end{array}$ from a "Flexible Curriculum" to improve the future professional competencies of your students, for example STEM?

22. Do you know and apply the 3 parts of the "flipped learning" model? a. $\quad \begin{array}{llllll}10 & 21 & 7 & 2 & 1\end{array}$ Review of video lessons at home. $b$. Meeting with the teacher-reinforcement.

c. Assignments to assimilate knowledge and evaluate the process.

\section{Analysis of Results}

Once the data collection instruments were applied, we proceeded to analyze them since the information they will yield will be the one that will indicate the conclusions reached by the research.

The results derived from the application of surveys in Quito in the Borja 3 Cavanis Educational Unit with 385 students from fifth grade to the third grade of high school with two parallel students each and 41 teachers of different subjects, it shows the questions represented in perception values. 
Table 7 according to the Likert scale from questions 1 to 9 has obtained a agree and agree in the survey conducted, with a percentage of 59 as the most significant on the use of digital resources, interactive games, virtual platforms, videos to develop and build knowledge in students. On the other hand, a percentage of 21 students agree that the teacher should send material before class hours in order to understand better the topic covered in class and to be able to perform the three moments required by the Flipped and Blended Learning model.

Table 7. Survey Score: Flipped \& Blended Learning—Students.

\begin{tabular}{|c|c|c|c|c|c|}
\hline & P1 & $\mathbf{P 2}$ & P3 & $\mathbf{P 4}$ & P5 \\
\hline Questions & $\begin{array}{l}\text { Totally Agree } \\
\text { Survey } \%\end{array}$ & $\begin{array}{c}\text { Agree } \\
\%\end{array}$ & $\begin{array}{c}\text { Undecided } \\
\%\end{array}$ & $\begin{array}{c}\text { In Disagreement } \\
\%\end{array}$ & $\begin{array}{c}\text { Strongly Disagree } \\
\%\end{array}$ \\
\hline Q1 & $39 \%$ & $28 \%$ & $22 \%$ & $2 \%$ & $9 \%$ \\
\hline $\mathrm{Q} 2$ & $59 \%$ & $29 \%$ & $8 \%$ & $1 \%$ & $3 \%$ \\
\hline$\widehat{\mathrm{Q}} 3$ & $36 \%$ & $34 \%$ & $22 \%$ & $5 \%$ & $3 \%$ \\
\hline$\widehat{\mathrm{Q}} 4$ & $46 \%$ & $35 \%$ & $13 \%$ & $3 \%$ & $3 \%$ \\
\hline$\widehat{Q} 5$ & $48 \%$ & $38 \%$ & $9 \%$ & $2 \%$ & $3 \%$ \\
\hline Q6 & $42 \%$ & $33 \%$ & $16 \%$ & $4 \%$ & $5 \%$ \\
\hline Q7 & $31 \%$ & $31 \%$ & $22 \%$ & $9 \%$ & $7 \%$ \\
\hline Q8 & $37 \%$ & $24 \%$ & $21 \%$ & $7 \%$ & $11 \%$ \\
\hline Q9 & $29 \%$ & $32 \%$ & $24 \%$ & $5 \%$ & $10 \%$ \\
\hline Q10 & $35 \%$ & $31 \%$ & $21 \%$ & $6 \%$ & $7 \%$ \\
\hline Q11 & $24 \%$ & $21 \%$ & $31 \%$ & $13 \%$ & $11 \%$ \\
\hline Q12 & $34 \%$ & $33 \%$ & $20 \%$ & $7 \%$ & $6 \%$ \\
\hline Q13 & $16 \%$ & $21 \%$ & $25 \%$ & $16 \%$ & $22 \%$ \\
\hline Q14 & $25 \%$ & $24 \%$ & $29 \%$ & $10 \%$ & $12 \%$ \\
\hline Q15 & $9 \%$ & $15 \%$ & $21 \%$ & $25 \%$ & $30 \%$ \\
\hline Q16 & $26 \%$ & $28 \%$ & $22 \%$ & $11 \%$ & $13 \%$ \\
\hline$\widehat{Q} 17$ & $39 \%$ & $40 \%$ & $13 \%$ & $4 \%$ & $4 \%$ \\
\hline Q18 & $19 \%$ & $25 \%$ & $28 \%$ & $13 \%$ & $15 \%$ \\
\hline Q19 & $44 \%$ & $23 \%$ & $10 \%$ & $7 \%$ & $16 \%$ \\
\hline Q20 & $18 \%$ & $18 \%$ & $22 \%$ & $14 \%$ & $28 \%$ \\
\hline Q21 & $48 \%$ & $23 \%$ & $13 \%$ & $8 \%$ & $8 \%$ \\
\hline$\widehat{\mathrm{Q}} 22$ & $19 \%$ & $25 \%$ & $22 \%$ & $12 \%$ & $22 \%$ \\
\hline
\end{tabular}

On the other hand, in question 10 with a percentage of 35 students with a response totally in agreement with the teacher acquiring a new way of teaching, where students are used to passively receiving their classes and a change can give good results since with the FL model students become autonomous and the teacher their guide.

In question 11, a percentage of 31 students are undecided about receiving virtual classes through platforms since this medium has been complicated by a lack of internet at home or an unstable connection. The most important thing is that students do not fully understand the activities sent on virtual platforms as in person or with the teacher in class, with a agree and agree on questions, with totally agree in question 12 with a percentage of 34 students think that the tasks given by teachers are precise when sending them home.

In the student's question, 14 with a percentage of 29 is undecided, since the projects and tasks sent by the teachers have not been interesting for the students so it is passively done traditionally without acquiring any new and innovative knowledge. However, according to the students they do not have difficulty learning and acquiring new knowledge from the teacher in their class hour and subject.

Similarly, in question 16, students are motivated in class to understand a new topic with a percentage of 28 agree and always have the help of their guide. The guide ever will be the teacher. Then, without failing to consider that students require that teachers use more technological resources in class and for their evaluations since they present 28 per cent 
of undecidedly in innovative technologies to know students' progress for their motivation and learning.

The YouTube platform for students in question 19 has become an innovative and essential tool in developing the knowledge acquired before the topics to be covered in class, with a percentage of 44 strongly agree. However, review question 20 with 28 is totally Disagree; the students think they could not learn a topic just by looking at the Internet and YouTube without the teacher being by their side.

Finally, in question 22, the students are undecided about the knowledge of the three moments of the use of Flipped and Blended Learning with 22 of percentage in agreeing, and another same value in totally disagree.

Table 8 according to the Likert scale, identifies the questions represented in values of perception by teachers, with a higher percentage of 50 in questions related to the use of technological tools, educational innovation, learning acquisition, use of ICTs, new learning models, training courses, development of activities using innovative digital tools, cooperative work, blended learning in face-to-face meetings and technology, evaluation methods, autonomous learning by the student, active participation, updating of skills and abilities, YouTube skills, vocational guidance from a flexible curriculum, use of Flipped Learning in classes.

With a percentage between 40 and 50 per cent, teachers require the use of new virtual environments in the subject. They believe that students would be motivated with a new learning model, and a new attitude would be achieved in the classroom. Likewise, acquiring a new FL learning model, in which students are active and not passive entities and receive constant evaluations and feedback from the teacher, on the other hand, it is thought that a formative evaluation with the use of rubrics increases the workload of teachers.

Table 8. Survey Score: Flipped \& Blended Learning-Teachers.

\begin{tabular}{cccccc}
\hline & $\mathbf{P 1}$ & $\mathbf{P 2}$ & $\mathbf{P 3}$ & $\mathbf{P 4}$ & $\mathbf{P 5}$ \\
\hline Questions & $\begin{array}{c}\text { Totally Agree } \\
\text { Survey } \%\end{array}$ & $\begin{array}{c}\text { Agree } \\
\mathbf{\%}\end{array}$ & $\begin{array}{c}\text { Undecided } \\
\mathbf{\%}\end{array}$ & $\begin{array}{c}\text { In Disagreement } \\
\%\end{array}$ & $\begin{array}{c}\text { Strongly Disagree } \\
\mathbf{\%}\end{array}$ \\
\hline Q1 & $67 \%$ & $29 \%$ & $2 \%$ & $0 \%$ & $2 \%$ \\
Q2 & $36 \%$ & $54 \%$ & $5 \%$ & $0 \%$ & $5 \%$ \\
Q3 & $49 \%$ & $46 \%$ & $3 \%$ & $0 \%$ & $2 \%$ \\
Q4 & $37 \%$ & $61 \%$ & $0 \%$ & $0 \%$ & $2 \%$ \\
Q5 & $54 \%$ & $37 \%$ & $7 \%$ & $0 \%$ & $2 \%$ \\
Q6 & $24 \%$ & $66 \%$ & $7 \%$ & $0 \%$ & $3 \%$ \\
Q7 & $39 \%$ & $59 \%$ & $0 \%$ & $0 \%$ & $2 \%$ \\
Q8 & $39 \%$ & $45 \%$ & $10 \%$ & $3 \%$ & $3 \%$ \\
Q9 & $41 \%$ & $46 \%$ & $7 \%$ & $3 \%$ & $3 \%$ \\
Q10 & $41 \%$ & $56 \%$ & $0 \%$ & $0 \%$ & $2 \%$ \\
Q11 & $46 \%$ & $50 \%$ & $2 \%$ & $0 \%$ & $3 \%$ \\
Q12 & $34 \%$ & $56 \%$ & $5 \%$ & $2 \%$ & $5 \%$ \\
Q13 & $41 \%$ & $46 \%$ & $8 \%$ & $0 \%$ & $5 \%$ \\
Q14 & $32 \%$ & $28 \%$ & $20 \%$ & $15 \%$ & $3 \%$ \\
Q15 & $50 \%$ & $47 \%$ & $0 \%$ & $0 \%$ & $2 \%$ \\
Q16 & $39 \%$ & $49 \%$ & $10 \%$ & $0 \%$ & $2 \%$ \\
Q17 & $29 \%$ & $51 \%$ & $17 \%$ & $1 \%$ & $3 \%$ \\
Q18 & $59 \%$ & $38 \%$ & $0 \%$ & $0 \%$ & $3 \%$ \\
Q19 & $32 \%$ & $63 \%$ & $2 \%$ & $0 \%$ & $2 \%$ \\
Q20 & $22 \%$ & $66 \%$ & $10 \%$ & $0 \%$ & $2 \%$ \\
Q21 & $24 \%$ & $68 \%$ & $5 \%$ & $1 \%$ & $2 \%$ \\
Q22 & $24 \%$ & $51 \%$ & $17 \%$ & $6 \%$ & \\
\hline
\end{tabular}

Figure 4 shows a comparison with the age range of students from the fifth grade to the third year of high school from 7 years old to over 16 years old regarding the use of technological resources in the classroom by the teacher, in which it can be observed 
that in all the age range with a totally agree and agree it is required that the teacher uses innovative technological tools in classes to increase in the student new knowledge and develop new skills in each subject.

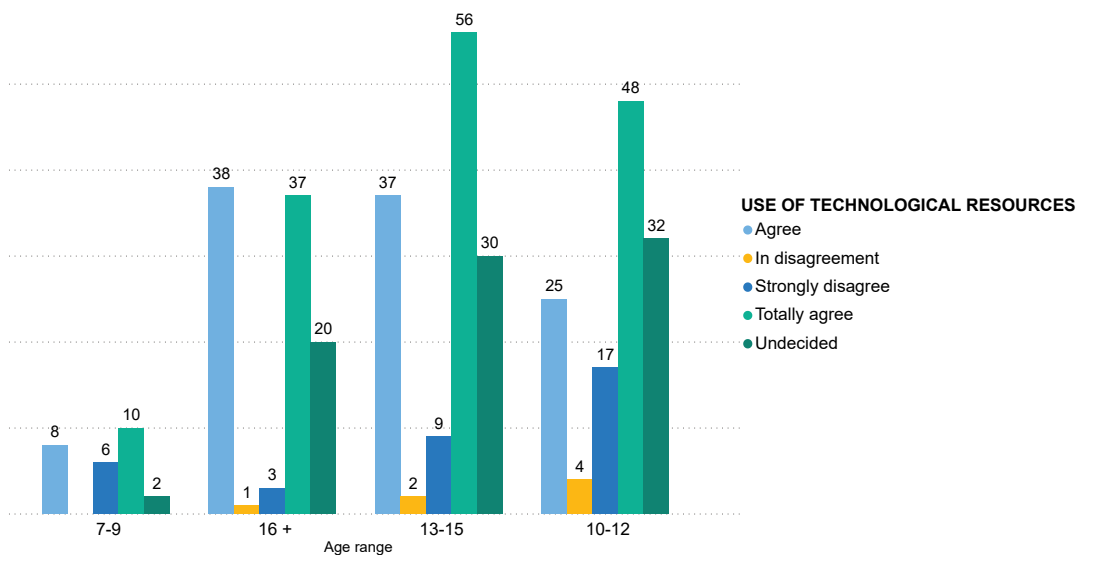

(a) Age range vs. Use of technological resources

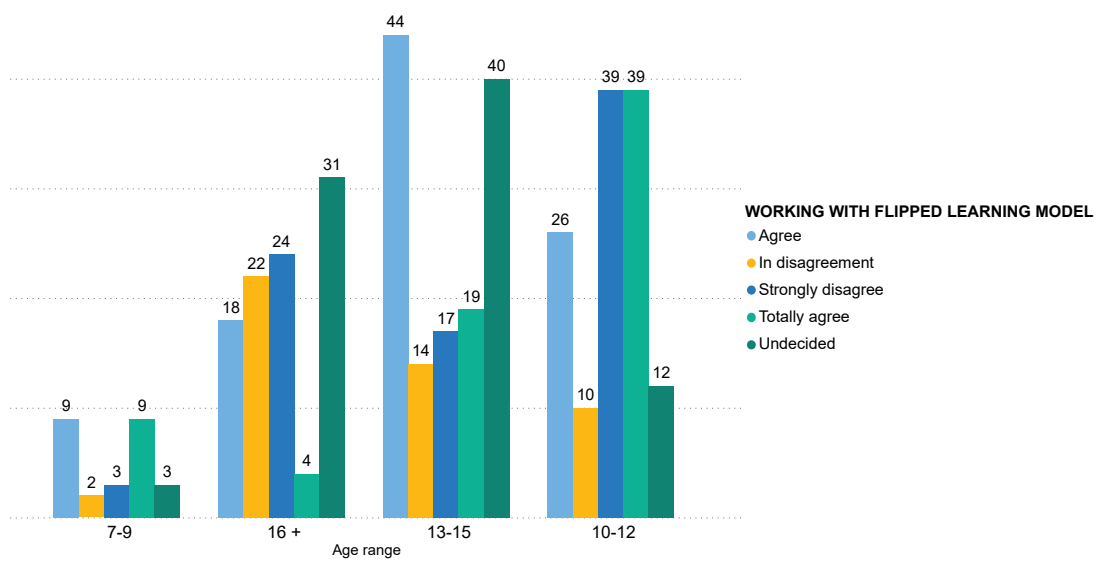

(b) Age range vs. Working with Flipped Learning model

Figure 4. Students survey: comparative analysis of results. (a) Use of technological resources. (b) Working with FL model. Source: Authors.

On the other hand, it can be observed that in the range of ages according to the use of this new learning model Flipped Learning in class with its three moments which are a review of video class at home, meeting with the teacher and its respective reinforcement and feedback and tasks to assimilate knowledge and evaluate the process, students from 7 to 9 and from 13 to 15 years old totally agree and agree that the teacher has used this new learning model in class, as well as half of the students from 10 to 12 years old totally agree. The other half totally disagree with using this new learning model, so students from 16 years old present an undecided answer and no knowledge about the use of Flipped Learning in class with their teachers.

Figure 5 shows a comparison with the educational levels of Primary school, Middle School and High School of the institution, where we can observe that with a totally disagree students think that they could not learn autonomously using the Internet and YouTube without the accompaniment of a teacher who is their guide, on the other hand, students in comparison with the educational levels with a totally agree think that they would like to have more knowledge of the subject to be treated before receiving class with the teacher, for which the use of FL and BL would be the best option of educational model in the 
institution since the student is prepared to use the three moments that these models entail in the classroom and become autonomous in learning and the teacher their guide.

Figure 6 shows a comparison in age range by teachers of the institution from 25 to more than 50 years of age where the importance of the student being autonomous in their learning and the teacher only their guide is considered, it can be seen that in ages 25 to 35 years an average of teachers agree that students are self-sufficient in the classroom and it is necessary to incorporate learning strategies and make them aware of how to learn, to achieve autonomous students and that the teacher is only their guide, with the use of affective-motivational strategies that help students to orient themselves and motivate them to carry out tasks, projects, and activities in class in order to gain confidence in their own abilities and skills, on the other hand, develop self-evaluation strategies that lead to self-evaluation in order to know the development and effort that the student has made autonomously in the development of knowledge as well as the FL and BL learning model, while another group of teachers presents an undecided response.

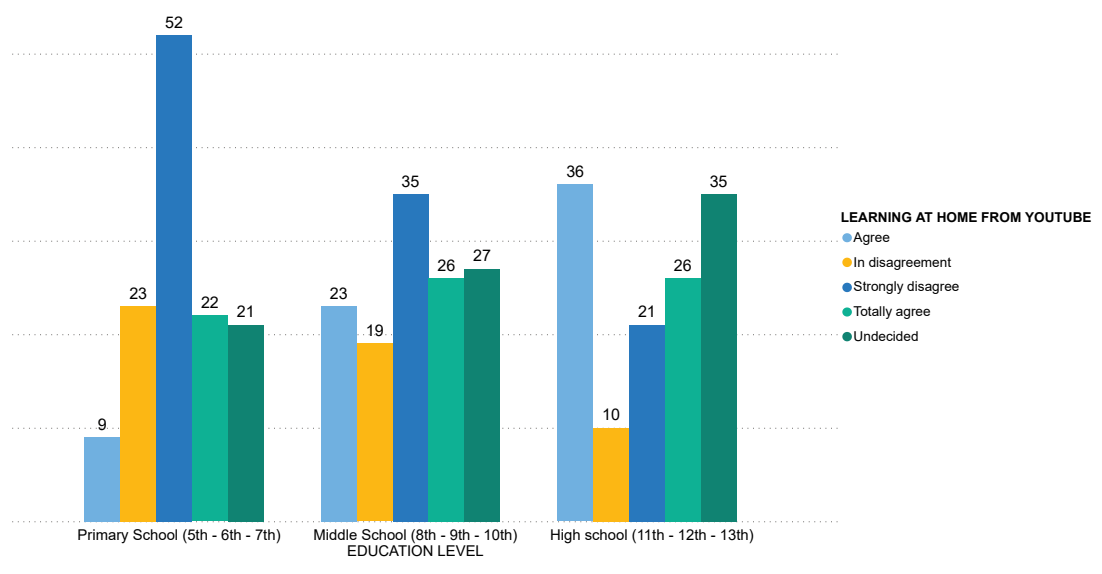

(a) Education level vs. Learning at home from YouTube

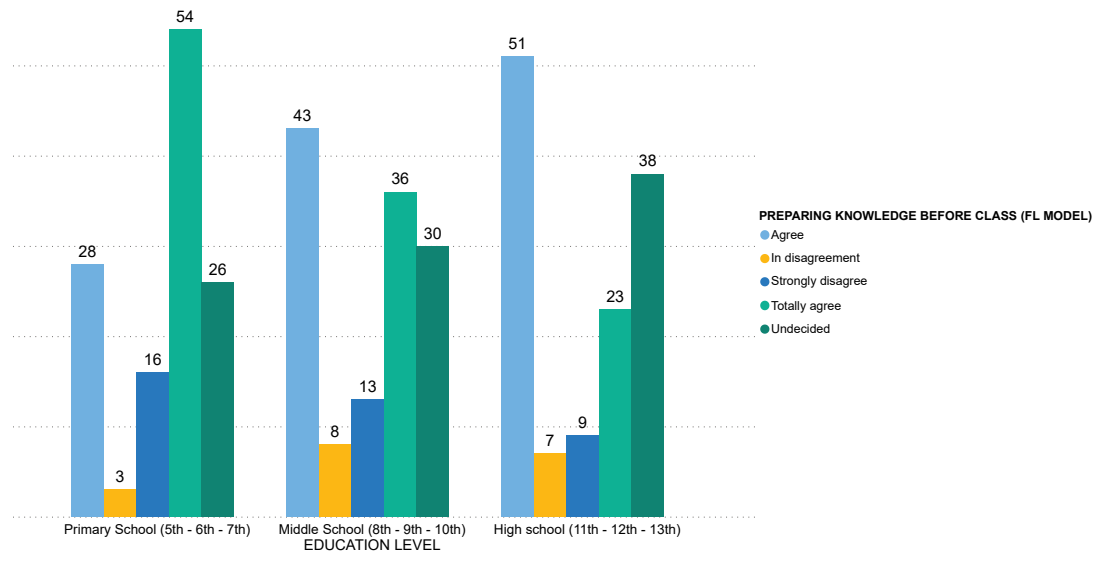

(b) Education level vs. Knowledge before class

Figure 5. Students Survey: comparative analysis of results. (a) Learning at home from YouTube. (b) Knowledge before class. Source: Authors. 


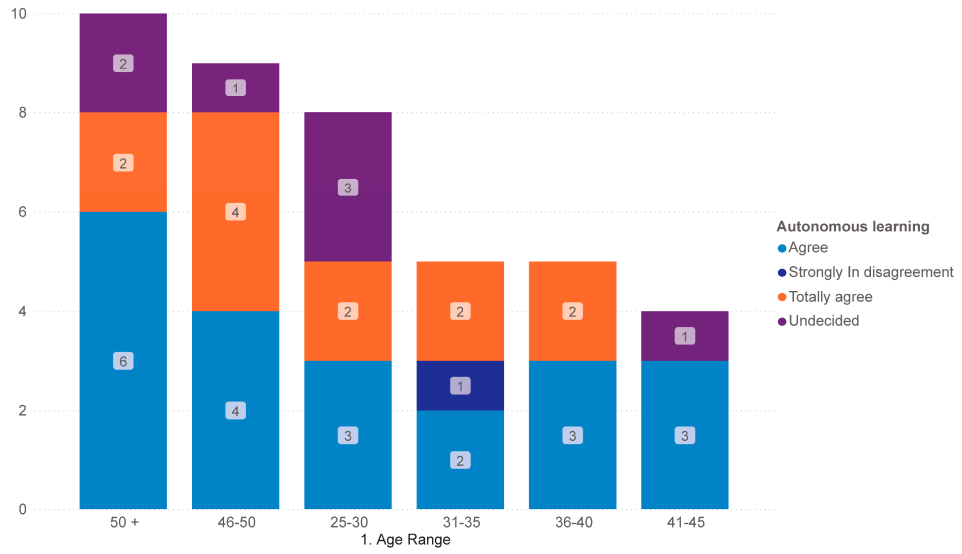

(a) Age range vs. Autonomous learning

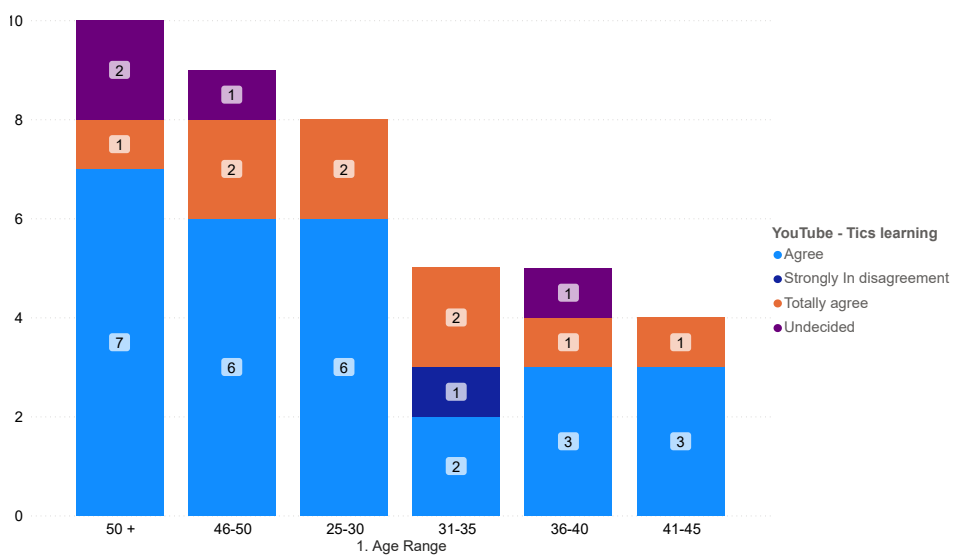

(b) Age range vs. YouTube - Tics learning

Figure 6. Teacher survey: comparative analysis of results. (a) Autonomous learning. (b) YouTube-Tics learning. Source: Authors.

From another perspective in age range, teachers think that in YouTube they can learn new competencies in Tics to improve the teaching-learning process in their students with an agreement from all the age range of teachers since it is considered that technology advances with speed never before considered. The work of the educator is to be at par with this evolution; the teacher must innovate when implementing these technological resources for their teaching, that is to say, they must be trained in the use of these; Since students are in the age of technology, for this reason, teachers and students should not be deprived of something as essential and essential as their autonomous education.

Figure 7 identifies a comparison with the educational levels of Middle School, High School and High School of the institution, in which teachers believe that vocational guidance should be encouraged from a Flexible Curriculum to improve the future professional competencies of their students with a positive response in agreement by teachers as well as STEM education. It is an interdisciplinary approach to learning that removes the traditional barriers of the four disciplines (Science-Technology-Engineering-Mathematics) and connects them to the real world with relevant experiences for students.

On the other hand, at the educational levels, the teacher knows and applies the three parts of the Flipped Learning model, which are: a review of video classes at home, meeting with the teacher-reinforcement and homework to assimilate knowledge and evaluate the process with an agreed response at all levels. 
Vocational and professional orientation is a dynamic, continuous, and progressive process carried out during all stages of the student's formation. The life project is a unique construction that considers the vocational and professional decisions made by a student.

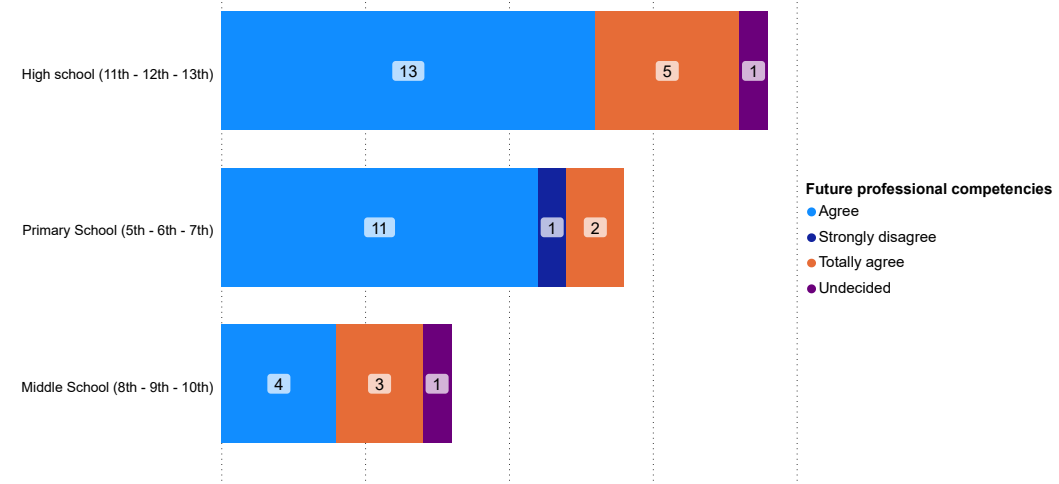

(a) Education level vs. Future professional competencies

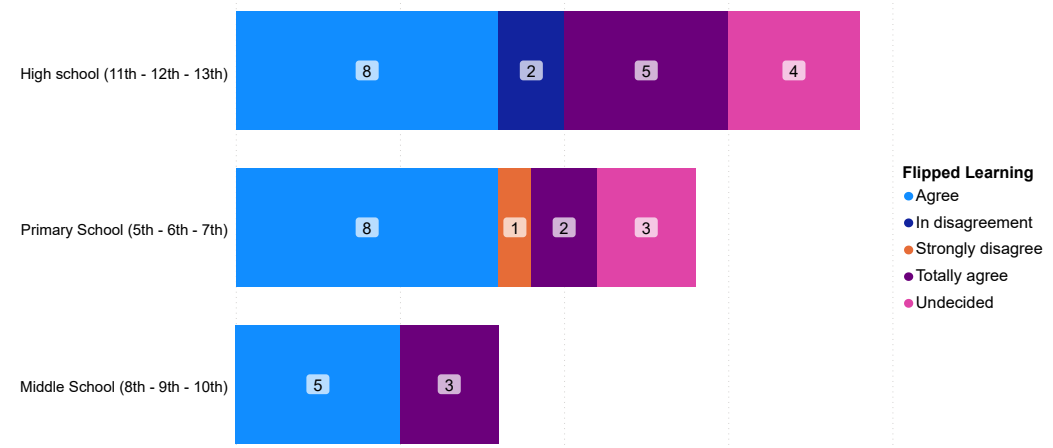

(b) Education level vs. Flipped Learning

Figure 7. Teacher survey: comparative analysis of results. (a) Future professional competencies. (b) Flipped learning Source: Authors.

\section{Conclusions}

This research aims to propose educational innovation in the evaluation processes in the inverted and combined learning models. Consequently, with the results obtained according to the surveys applied, it is concluded that students need the implementation of technological resources in the different subjects, evaluations, feedback and development in the classroom in order to increase the teaching-learning process significantly and that students expand their knowledge.

On the other hand, future generations should be encouraged in activities that develop competencies, new forms of evaluation that involve emotional intelligence, cooperative and autonomous work, that take into account multiple intelligence and above all, the use of ICT to implement active methodologies that give the students a leading role and leave behind the so-called "traditional school".

This article shows the relationship between the inverted and combined learning model in face-to-face and synchronous education scenarios since it can be known that using these new learning models in the classroom in a synchronous way where their learning is based on problems, practices, discussions. However, by relating and using these models in the classroom in a face-to-face and synchronous way, the student's capacity is developed through technological tools in the two fields of study, and their education becomes more flexible and active. 
Another essential point of view is the relationship of educational innovation within a hybrid model, which is a form of teaching that combines face-to-face and remote teaching tools and resources to improve the student's experiences and the learning process, carried out at a distance where students can control their time, space and pace of their activities and the other part carried out with the accompaniment of the teacher. In the same way, the resources of face-to-face and remote teaching can be combined when inverted, and combined learning is used in a remarkable way to implement active learning, foster meaningful learning, promote student-to-student interaction, which leads to cooperation and thus students have greater control over their learning, thus fostering autonomy.

The results of the bibliometric analysis can be explained according to the countries and universities with more relevance in the use of FL and BL learning models in recent years in education, taking into account the use of innovative technological resources to improve the quality and adequacy of the teaching-learning processes. In both universities and countries, teachers' digital competence has a fundamental role in the implementation and effectiveness of the different resources and didactic approaches, highlighting in this research the Flipped and Blended Learning as innovative educational models.

It is important to emphasize that students require autonomous learning before their class hours to understand the topics better to be covered and that it is collaborative, where the teacher is only their guide. On the other hand, teachers require students to foster a vocational orientation that can improve their future professional skills, teamwork, professional integrity, decision making and problem-solving, and intellectual skills such as motivation, leadership and decision making.

Finally, Flipped and Blended Learning models are successful in several countries and universities in improving their students' competencies, skills, and abilities, thus highlighting that the use of innovative technological resources is essential in these scenarios, both face-to-face and synchronous.

Author Contributions: M.Y. conceptualized the study, analyzed the data, and wrote the initial draft. E.I. analyzed the data, and revised the draft. M.Y. provided critical feedback and edited the manuscript. E.I. provided Zoom support and critical feedback. All authors read and approved the final manuscript.

Funding: This work was supported by Universidad Politécnica Salesiana and GIREI, Smart Grid Research Group under the project Flipped Learning and Blended Learning. Funding was also provided by the Smart Grid \& Smart Cities Research Group, RECI-IUS.

Institutional Review Board Statement: Not applicable.

Informed Consent Statement: Informed consent was obtained from all subjects involved in the study.

Data Availability Statement: Not applicable.

Acknowledgments: This work was supported by Universidad Politécnica Salesiana and GIREI —Smart Grid Research Group, and the master's program in Educational Innovation. Founding was also provided by the Network IUS-RECI-Smart Grid and Smart Cities.

Conflicts of Interest: The authors declare no conflict of interest.

\section{References}

1. Yang, L.; Wang, J.; Chen, P.; Pan, L.; Zhao, M. Design and Practice of Flipping Classroom under Blended Learning. In Proceedings of the 2020 IEEE 3rd International Conference on Information Systems and Computer Aided Education (ICISCAE), Dalian, China, 27-29 September 2020; pp. 179-182. [CrossRef]

2. Inga, E.; Inga, J.; Cárdenas, J. Planning and Strategic Management of Higher Education Considering the Vision of Latin America. Educ. Sci. 2021, 11, 188. [CrossRef]

3. Artal-Sevil, J.S.; Gargallo-Castel, A.F.; Valero-Gracia, M.S. Flipped teaching and interactive tools. A multidisciplinary innovation experience in higher education. In Proceedings of the 6th International Conference on Higher Education Advances (HEAd'20), Valencia, Spain, 2-5 June 2020; pp. 1-8. [CrossRef]

4. Tolk, A.; Harper, A.; Mustafee, N. Hybrid models as transdisciplinary research enablers. Eur. J. Oper. Res. 2021, 291, 1075-1090. [CrossRef] [PubMed] 
5. Rasheed, R.A.; Kamsin, A.; Abdullah, N.A. Challenges in the online component of blended learning: A systematic review. Comput. Educ. 2020, 144, 103701. [CrossRef]

6. Inga, E.; Inga, J. Innovación Educativa para Gestión y Planeación de la Educación Superior Basado en Responsabilidad Social. In Estrategias Didácticas para la Innovación en la Sociedad del Conocimiento; CIMTED: Antioquia, Colombia, 2019; pp. 13-35.

7. Nayar, B.; Koul, S. Blended learning in higher education: A transition to experiential classrooms. Int. J. Educ. Manag. 2020, 34, 1357-1374. [CrossRef]

8. Mohamed, H.; Lamia, M. Implementing flipped classroom that used an intelligent tutoring system into learning process. Comput. Educ. 2018, 124, 62-76. [CrossRef]

9. Fisher, R.L.; LaFerriere, R.; Rixon, A. Flipped learning: An effective pedagogy with an Achilles' heel. In Innovations in Education and Teaching International; Routledge: London, UK, 2020; Volume 57, pp. 543-554. [CrossRef]

10. Bruggeman, B.; Tondeur, J.; Struyven, K.; Pynoo, B.; Garone, A.; Vanslambrouck, S. Experts speaking: Crucial teacher attributes for implementing blended learning in higher education. In Internet and Higher Education; Elsevier Inc.: Amsterdam, The Netherlands, 2021; Volume 48, p. 100772. [CrossRef]

11. Sari, R.; Napitupulu, T.A. Evaluation Blended Learning Model in Higher Education. In Proceedings of the 2018 International Conference on Information Management and Technology (ICIMTech), Jakarta, Indonesia, 3-5 September 2018 ; pp. 417-422. [CrossRef]

12. Munir, M.T.; Baroutian, S.; Young, B.R.; Carter, S. Flipped classroom with cooperative learning as a cornerstone. In Education for Chemical Engineers; Institution of Chemical Engineers: Amsterdam, The Netherlands, 2018; Volume 23, pp. 25-33. [CrossRef]

13. Smith, K.D. Is it face time or structure and accountability that matter? Moving from a flipped to a flipped/hybrid classroom. $J$. Appl. Res. High. Educ. 2021, 13, 609-621. [CrossRef]

14. Zydney, J.M.; Warner, Z.; Angelone, L. Learning through experience: Using design based research to redesign protocols for blended synchronous learning environments. Comput. Educ. 2020, 143, 103678. [CrossRef]

15. Yang, J.; Yu, H.; Chen, N.S. Using blended synchronous classroom approach to promote learning performance in rural area. Comput. Educ. 2019, 141, 103619. [CrossRef]

16. Inga, E.; Hincapié, R. Creación de artículos académicos basados en minería de datos y Web 2.0 para incrementar la producción científica en ingeniería. Rev. Educ. Ing. 2015, 10, 65-74. [CrossRef]

17. Hao, W.; Huiyan, L. Research on Blended Teaching Reform and Innovation Strategy Based on MOOC Education. In Proceedings of the 2018 13th International Conference on Computer Science \& Education (ICCSE), Colombo, Sri Lanka, 8-11 August 2018; Volume 1515, pp. 1-4. [CrossRef]

18. Dalipi, F.; Kurti, A.; Zdravkova, K.; Ahmedi, L. Rethinking the conventional learning paradigm towards MOOC based flipped classroom learning. In Proceedings of the 2017 16th International Conference on Information Technology Based Higher Education and Training (ITHET), Ohrid, Macedonia, 10-12 July 2017; pp. 1-6. [CrossRef]

19. Gürsoy, G.; Orhan Göksün, D. Flipped learning: As a solution for course duration. In Computer Applications in Engineering Education; Wiley: Hoboken, NJ, USA, 2020; p. cae.22264. [CrossRef]

20. Chen, W.T.; Lee, C.Y.; Chang, C.K.; Wu, T.C.; Meen, T.H.; Tsai, J.K. Flipped Classroom of Science instruction module “Do, Learn, Think, Share", with its development and effectiveness evaluation. In Proceedings of the 2018 1st IEEE International Conference on Knowledge Innovation and Invention (ICKII), Jeju Island, Korea, 23-27 July 2018; pp. 184-186. [CrossRef]

21. Fauziah, N.; Bakar, A.; Sukiman, S.A.; Yusop, H. Regional Conference on Science, Technology and Social Sciences (RCSTSS 2014). Reg. Conf. Sci. Technol. Soc. Sci. 2016, 2041, 611-620. [CrossRef]

22. Umezawa, K.; Ishida, T.; Nakazawa, M.; Hirasawa, S. Evaluation by Questionnaire on Grouped Flipped Classroom Method. In Proceedings of the 2018 IEEE 10th International Conference on Engineering Education (ICEED), Kuala Lumpur, Malaysia, 8-9 November 2018; pp. 83-88. [CrossRef]

23. Zhang, H.; Meng, L.; Han, X.; Yuan, L.; Wang, J. Exploration and Practice of Blended Learning in HVAC Course Based on Flipped Classroom. In Proceedings of the 2016 International Symposium on Educational Technology (ISET), Beijing, China, 19-21 July 2016; pp. 84-88. [CrossRef]

24. Xie, X.; Li, X. Exploration and Practice of Process Assessment and Evaluation Method Based on Blended Learning-Take programming courses as an example. In Proceedings of the 2020 2nd International Conference on Advances in Computer Technology, Information Science and Communications (CTISC), Suzhou, China, 10-12 July 2020; pp. 85-89. [CrossRef]

25. Porter, W.W.; Graham, C.R. Institutional drivers and barriers to faculty adoption of blended learning in higher education. $\mathrm{Br}$. J. Educ. Technol. 2016, 47, 748-762. [CrossRef]

26. Colomo-Magaña, E.; Soto-Varela, R.; Ruiz-Palmero, J.; Gómez-García, M. University Students' Perception of the Usefulness of the Flipped Classroom Methodology. Educ. Sci. 2020, 10, 275. [CrossRef]

27. Zhou, X.; Chen, L.H.; Chen, R.C. Measuring student mental readiness for flipped blended learning: Scale development and validation. In Proceedings of the 2017 IEEE 8th International Conference on Awareness Science and Technology (iCAST), Taichung, Taiwan, 8-10 November 2017; pp. 161-164. [CrossRef]

28. Awidi, I.T.; Paynter, M. The impact of a flipped classroom approach on student learning experience. Comput. Educ. 2019, 128, 269-283. [CrossRef] 
29. Tsai, M.N.; Liao, Y.F.; Chang, Y.L.; Chen, H.C. A brainstorming flipped classroom approach for improving students' learning performance, motivation, teacher-student interaction and creativity in a civics education class. Think. Ski. Creat. 2020, $38,100747$. [CrossRef]

30. Chilingaryan, K.; Zvereva, E. Methodology of Flipped Classroom as a Learning Technology in Foreign Language Teaching. Procedia Soc. Behav. Sci. 2017, 237, 1500-1504. [CrossRef]

31. Koes-H, S.; Putri, F.S.; Purwaningsih, E.; Salim, A.Y. The influence of flipped classroom in inquiry learning to student's critical thinking skills in impulse and momentum. AIP Conf. Proc. 2020, 2215, 050008. [CrossRef]

32. Yao-Hua, S. The Construction of Excellent Teachers' Teaching Evaluation System in the Blended Learning Environment. In Proceedings of the 2017 9th International Conference on Measuring Technology and Mechatronics Automation (ICMTMA), Changsha, China, 14-15 January 2017; pp. 455-459. [CrossRef]

33. Markic, M.; Volaric, T. Usage of the Blended Learning Model at the Faculty of Education. In Proceedings of the 2018 26th International Conference on Software, Telecommunications and Computer Networks (SoftCOM), Split, Croatia, 13-15 September 2018; pp. 1-6. [CrossRef]

34. López-Pellisa, T.; Rotger, N.; Rodríguez-Gallego, F. Collaborative writing at work: Peer feedback in a blended learning environment. Educ. Inf. Technol. 2021, 26, 1293-1310. [CrossRef]

35. Andujar, A.; Nadif, F.Z. Evaluating an inclusive blended learning environment in EFL: A flipped approach. In Computer Assisted Language Learning; Routledge: London, UK, 2020; pp. 1-30. [CrossRef] 